\title{
TEXT IMPLEMENTATION OF THE CONCEPT SUCCESS IN THE NOVEL "ELON MUSK. TESLA, SPACEX, AND THE QUEST FOR A FANTASTIC FUTURE” BY ASHLEE VANCE
}

\begin{abstract}
Summary. The article deals with the textual implementation of the concept SUCCESS in Ashley Vance's novel Elon Musk. Tesla, SpaceX, and the Quest for a Fantastic Future. The concept SUCCESS holds a particular place in the English-speaking world mapping. Nowadays SUCCESS has three groups of meanings in the English-language picture of the world: the first one is related to luck and successful result; the second one is connected with the well-being, material well-being; and the third one to the recognition that can be related to both inanimate objects and people who are successful. The concept SUCCESS has undergone many stages of cultural and historical evolution, eventually becoming a strong and functional national idea. The concept SUCCESS in the analyzed novel is mostly concerned with: Elona Musk's figure as a successful personality; companies created by Elon Musk; other individuals and companies mentioned by the author. The lexical-semantic field of the concept SUCCESS which mainly exists in the novel around Ilona Musk's personality, is actively verbalized by a number of lexical-semantic means of different linguistic levels. The semantic features of such lexemes are divided into the following groups: names of people by spheres of activity, by inner qualities, by characteristics that indicate the relation of the environment and personality to oneself; names related to physical and mental characteristics and words to indicate action and status. An analysis of the lexical-semantic field of the SUCCESS concept has shown that the creation of an image of a successful person is achieved through the use of various lexical-semantic means among which words have been found to be predominant in terms of action and status. This indicates that action is an important factor in the path to success, although, undoubtedly, the internal and external qualities of the person, the attitude of the society and the individual's attitude to his personality, as well as the nature of his activities play an important role in the process of success.
\end{abstract}

Key words: concept, world picture, SUCCESS, lexical-semantic field, verbalization.

Target setting. SUCCESS is one of the topical conceptsintoday's world language picture. Nowadays it is customary to characterize people not by their physical or psychological characteristics, but by their achievements in life, that is how successful they are. Success is now interpreted not as something ephemeral, unattainable, but as an opportunity that is accessible to everyone, the main thing is what each person does to gain this opportunity.

Thus success in today's society is largely understood as a positive result of activity, not as a result of possessing extraordinary abilities or talent, as it was before. It is clearly proved by recent movies ("The Founder" (by John Lee Hancock), "The Pursuit of Happiness" (by Gabriele Muccino), "The Intern" (by Nancy Jane Meyers) etc.), articles and books ("Strategy Rules: Five Timeless Lessons from Bill Gates, Andy Grove, and Steve Jobs" by David B. Yoffie and Michael A. Cusumano, "Shoe Dog: A Memoir by the Creator of Nike" by Phil Knight etc.) that tell the story of success for the average person. One of the similar novels is "Elon Musk. Tesla, SpaceX, and the Quest for a Fantastic Future" by Ashlee Vance where the author is trying to find the reasons for the rapid success of one of the richest people in the world - Elon Musk. The concept SUCCESS in this novel is verbalized quite actively, and since the book is written by an American and created primarily for an American audience, it is undoubtedly possible to observe the peculiarities of the American national linguistic picture of the world, the American mentality through the embodiment of the concept SUCCESS.

Research analysis. The problem of describing the essence of the concept remains relevant to modern linguistic science. The concept category is investigated in the scientific works of linguists M. Anhelova [1], A. Wierzbicka [2], N. Volodina [3], S. Vorkachov [4; 5], A. Zahnitko [6], V. Karasik [7], V. Kolesov [9], V. Kononenko [10], A. Pryhodko [11], L. Cherneiko [12] etc. Such a large number of scientific developments once again testifies the conceptual direction in modern linguistics and indicates the relevance of the study of the conceptual linguistic sphere.

Thus the purpose of the article is to investigate the peculiarities of the textual implementation of SUCCESS concept defining the constituents of its lexical-semantic field.

The body. One way to access the content of concepts is to study their semantics. Semantics of virtually any concept is extremely broad. It encompasses not only some meaning directly to the concepttoken, but also to associations, emotions, representations, layers of personal experience as a native speaker and of the whole ethnos. Therefore in the study of the concept there is a need to study those lexical units that together with the word-name make up its lexicalsemantic field.

The lexical-semantic field is the merge of the meanings of words that contain specific concepts that differ in their degree of quality, features, actions, and contrasting qualities of a feature, action, object, and phenomenon. It is formed in the process of interaction of linguistic and extra linguistic factors and its components are various kinds of common semantic components, semantic derivatives, semantic nets in which semantic identities, opposites, etc. are realized [8].

The main criteria for selection of elements in a specific lexicalsemantic field are:

- general semantic feature, general lexical meaning of the field elements; 
- general function;

- subject area union;

- the presence of one or more views about a particular phenomenon of reality.

The most common criterion for selecting items into a specific lexical-semantic field is a general semantic feature. It is also called "seme" in linguistics. This feature is used by scientists in the study of linguistic phenomena by the method of component analysis which involves the separation of semantic components of the meaning of words. Values include a set of features that verbalize the concept. Such a set of semantic features consists of smaller, hierarchically ordered and semantically indivisible elements, semes.

To determine the composition of the lexical-semantic field of the SUCCESS concept in Ashley Vance's book "Elon Musk. Tesla, SpaceX, and the Quest for a Fantastic Future" a sample of lexical elements related to the studied concept was analyzed and their semantics analyzed.

It should be noted that the word success and its co-root words (successful, successfully) are used rarely in the text of the analyzed work not really often. However, given that the text of the biography itself is a story about the success of Elon Musk, it is clear that the author uses different lexical correspondences which form the lexical-semantic field of SUCCESS concept. It should be emphasized that SUCCESS concept in the analyzed work is mostly concerned with:

1. Elon Musk as a successful personality:

"Yet, in the early part of 2012, the cynics like me had to take notice of what Musk was actually accomplishing " [14].

2. Companies created by Elon Musk:

"During a time in which clean-tech businesses have gone bankrupt with alarming regularity, Musk has built two of the most successful clean-tech companies in the world" [14].

3. Other personalities and companies mentioned by the author:

"Only Steve Jobs could claim similar achievements in two such different industries, sometimes putting out a new Apple product and a blockbuster Pixar movie in the same year" [14].

Considering the lexical-semantic field of SUCCESS concept that exists in the work around Elon Musk's personality, it turns out to be most actively verbalized. By their nature the analyzed units constitute a complex and heterogeneous array of vocabulary. By analyzing semantic features of such lexemes by parts of language classes we can divide them into the following groups:

1) Names of people by:

- activity:

"He was also the chairman and largest shareholder of SolarCity, a booming solar energy company poised to file for an initial public offering" [14].

Such names indicate that the success of a certain individual depends on the type of activity. For example, the lexeme chairman is defined in the Cambridge Dictionary as "a person in charge of a meeting, organization, or department" [13]. An important characteristic here is "in charge" which indicates that a successful person is responsible for something - for the company, for other people and so on.

Shareholder is "a person who owns shares in a company and therefore gets part of the company's profits and the right to vote on how the company is controlled" [13]. The important feature such as "owns" is quite important in this example that is, a successful person necessarily owns something - assets, company, wealth, etc.
- inner qualities: sheepish, confident, charming, intriguing, eager, insane, rich, famous, successful etc., for example:

"Instead, he tends to be almost sheepish" [14];

"He's a confident guy, but does not always do a good job of displaying this" [14].

Confident means "being certain of your abilities or having trust in people, plans, or the future" [13]. The key word "abilities" points out that being confident and therefore successful cannot be without certain abilities that can help you succeed.

"Musk, in fact, will toss out plenty of jokes and can be downright charming" [97, c. 19]. Charming is used "to describe people who use their attractiveness to influence people or to make other people like them" [13]. In this example the key lexeme is "to influence" which indicates that attractive, and therefore successful people interact with other people in one way or another, even if that interaction is based on one-sided influence in order to succeed.

"Cantrell found Musk both intriguing and all too eager" [14].

Intriguing means "very interesting because of being unusual or mysterious" [13]. Thus it is indicated that the successful person is usually interested in the environment in which he is or attracts attention. Eager means "having or showing desire or interest" [13], that is, desire and interest are what differentiate a successful person from an ordinary one.

"The Musk Co. empire of factories, tens of thousands of workers, and industrial might has incumbents on the run and has turned Musk into one of the richest men in the world, with a net worth around \$10 billion" [14]. Rich means "having a lot of money or valuable possessions" [14]. In this example the direct connection with the word "money" is evident, that is with material values as a pledge of a successful person.

"This collection of super-bright employees has become known as the PayPal Mafia-more or less the current ruling class of Silicon Valley - and Musk is its most famous and successful member" [14]. Famous means "known by very many or most people" [13], that is, success is impossible without recognition by other people. Successful stands for "achieving desired results, or achieving the result of making a lot of money" [13]. Achievement is the key here that is as we can see success is associated with achievement.

"I'd long been a subscriber to this latter camp. Musk had struck me as a well-intentioned dreamer - a card-carrying member of Silicon Valley's techno-utopian club" [14]. Dreamer is "a person who spends a lot of time thinking about or planning enjoyable events that are not likely to happen" [13] which is an important feature associated with the concept SUCCESS meaning "spends a lot of time". Thus a successful person devotes a lot of time to a particular activity, even the dreams of the future.

"He's the possessed genius on the grandest quest anyone has ever concocted" [14].

Genius is "very great and rare natural ability or skill, especially in a particular area such as science or art, or a person who has this" [13] defining an important feature of "rare natural ability or skill" meaning that successful people must have some skills or talents otherwise they are not different from other people.

We see how heterogeneous the internal characteristics of a successful personality are. A particular interest is taken by the lexeme insane that is used in the text a few times: "What Elon is doing is insane" [14].

Insane means "extremely unreasonable or mentally ill" [13]. Thus in the modern world a successful person is understood not 
only as having a "standard" set of qualities (mind, perseverance, etc.), but also having extraordinary ideas and his or her own vision of what the world should be like, that is in a sense, "abnormal" compared to other people. But that is what allows them to succeed.

It is also worth noting the abundant use of comparative adjectives: most famous, better, more ambitious etc.: "If you really are better than most hedge fund managers, then there is no need to worry about the value of your SpaceX stock, as you can just invest in other public company stocks and make billions of dollars in the market" [14].

Better indicates "of a higher standard or less poor quality; not as bad as something else; more suitable or appropriate; more able; showing more skill" [13]. The last definition - "showing more skill"is, in our opinion, the most obvious in the context of interpreting the concept of SUCCESS because the best is considered a person who has certain skills and skills that other people do not have which is the reason for success.

"Musk was more ambitious in college than he'd been in high school" [14]. Ambitious implies "determined to be successful, rich, powerful, etc." [13]. Here in the very definition of the word we see its direct connection with the concept of SUCCESS, because ambition is one of the key characteristics of a successful person.

"Things like physics and computers - I got the highest grade you can get in those" [14]. High has the meaning of "greater or better than normal in quantity or quality, size or degree" [13]. Grade means "a mark given in an exam or for a piece of school work" [13]. Thus, the semantic field of SUCCESS concept also includes words to denote the evaluation obtained in the course of a particular activity. And this assessment, as we see, should be the highest only then can we talk about the success of the individual.

"The hardest job Musk took came after a visit to the unemployment office" [14]. Hard means "needing or using a lot of physical strength or mental effort" [13]. So, success correlates with effort, both physical and mental. And the highest degree of comparison of the adjective "the hardest" only emphasizes the importance of these efforts.

A large number of signifying lexemes for SUCCESS concept testifies to the active and fruitful search by the author of the analyzed biography for new expressive means of denoting static signs of success. The presence of the following nominal units in the lexical-semantic field of SUCCESS concept indicates that the inborn qualities, namely the elements of character, temperament, compel the person to act in one way or another, either resulting in success or not:

1) characteristics that indicate the attitude of the environment and personality to oneself: "Musk's ready willingness to tackle impossible things has turned him into a deity in Silicon Valley, where fellow CEOs like Page speak of him in reverential awe, and budding entrepreneurs strive "to be like Elon" just as they had been striving in years past to mimic Steve Jobs" [14]. Deity means "a god or goddess" [13]. Thus, a successful person is compared to the one who has supernatural abilities, a "divine" power and as such that is perceived by other people as a deity.

"These two feats elevated Musk to the rarest heights among business titans" [14]. Titan stands for "a person who is very important, powerful, strong, big, clever, etc." [13]. Here we see important psychological characteristics of a successful person important, powerful, strong, intelligent, etc., and in combination with the lexeme business - "the activity of buying and selling goods and services" [13] the whole semantic potential of this word is manifested, since it indicates the power in the sphere of business, that is, in the sphere of certain activity.

"I am a billionaire" [14]. Billionaire is "a person who has money, property, etc. that is worth at least 1,000,000,000 dollars, pounds, euros, etc." [13]. Here we see the important characteristics of successful people who find themselves in monetary terms.

The lexemes indicating the attitude of the environment and personality to oneself, in our opinion, are extremely important because it is proved that these are the opinion and attitude that determine the subsequent actions of people: if they consider themselves to be incapable such people are unlikely to succeed and vice versa;

2) abstract titles (often created from verbs):

"He's willing to take an insane amount of personal risk" [14]. Risk is "doing something although there is a chance of a bad result" [13]. The key lexeme is "doing", that is, a successful person is distinguished by what he or she does, even if there is no $100 \%$ guarantee of the success of such actions.

"Musk's ready willingness to tackle impossible things has turned him into a deity in Silicon Valley, where fellow CEOs like Page speak of him in reverential awe, and budding entrepreneurs strive "to be like Elon" just as they had been striving in years past to mimic Steve Jobs" [14]. Willingness is "the quality of being happy to do something if it is needed" [13]. Again we see the attachment to the verb "to do", that is, to act as a characteristic of human success which is impossible without the self-motivation of the person "being happy". "It's just that there's a sense of purpose and pressure hanging over any conversation with the man" [14]. Purpose means "an intention or aim; a reason for doing something or for allowing something to happen" [13]. Another case of the important lexeme "doing" is observed which is supported by strong inner feeling, purposefulness of the nouns "intention" and "aim" and the presence of a certain impulse "reason" to action.

"It's the guy who owns the joint and strides about with authority" [14]. Authority is "the power to control or demand obedience from others" [13] where the lexemes "to control" and "to demand obedience" indicate the full authority of a successful person over other less successful individuals.

As we can see, the nouns that make up the lexical-semantic field of SUCCESS concept are characterized by heterogeneity and are the manifestation of the general tendency for the active use of nominatives in the characterization of certain phenomena;

3) signs related to physical characteristics:

"He's absurdly broad-shouldered, sturdy, and thick" [14]. Sturdy means "physically strong and solid or thick, and therefore unlikely to break or be hurt" [13] where "strong" indicates a certain pass from the physical levels to the psychological one as a strong person can manifest his or her strong character in physical way.

It is well known that the appearance, or rather the signal that transmits the appearance of a person to others, is an important factor in achieving success or not succeeding. Yet it is very difficult for a person who shows insecurity, fear, etc. to succeed. Instead, the appearance of Elon Musk, on the contrary, compels others to see him as self-confident and therefore a successful personality:

"You'd figure he would use this frame to his advantage and perform an alpha-male strut when entering a room" [14];

4) words denoting an action or state, the semantics of which are, respectively, represented by two main semes: 
a) action: to try, to make, to tackle, to accomplish, to own, to stride, to build, to invest, to prove, to use etc.

"Musk fully intends to try and make this happen" [14]. To try means "to attempt to do something" [13]. Once again one can observe connection to the verb "to do" that is, to act as the determining criterion for success.

"Musk's ready willingness to tackle impossible things has turned him into a deity in Silicon Valley, where fellow CEOs like Page speak of him in reverential awe, and budding entrepreneurs strive "to be like Elon" just as they had been striving in years past to mimic Steve Jobs" [14]. In this example to tackle has the meaning "to try to deal with something or someone" [13], so again we see the correlation of success with the action which is further supported by the strong internal meaning of the noun "willingness".

"Yet, in the early part of 2012, the cynics like me had to take notice of what Musk was actually accomplishing" [14]. To accomplish means "to finish something successfully or to achieve something" [13]; so as we can see the important characteristic of successful activity is the completion of the action with a positive, successful outcome that has a visible result.

"Musk's decision to invest so much money in X.com looks even more unusual in hindsight. Much of the point of being a dotcom success in 1999 was to prove yourself once, stash away your millions, and then use your credentials to talk other people into betting their money on your next venture" [14].

To invest means "to put money, effort, time, etc. into something to make a profit or get an advantage" [13] while to prove means "to show a particular result after a period of time" [13]. In both cases the key word is result it is only by having a certain result that one can prove their success. However in order to do this something has to be invested into their business (money, time and effort).

As we can see, action plays an extremely important role in succeeding because certain results can be achieved only by moving forward; any success, any business is impossible without action and effort;

b) state words:

"He's willing to take an insane amount of personal risk" [14].

To will means "to use the power of mind to do something or to make something happen" [13] which proves that inner state plays a significant role in succeeding. It determines the wishes and aims turning them into action.

"It's the guy who owns the joint and strides about with authority" [14]. The lexeme who owns the joint means «the one who is the most important» showing the state as the advantage of one person over others. An ordinary guy who has succeeded in his business now owns the time of people who work for him.

"On the other hand, Musk's companies have already accomplished far more than his loudest detractors thought possible, and the promise of what's to come has to leave hardened types feeling optimistic during their weaker moments" [14].

"Optimism feeling", thus, is one of the keys to success, especially at difficult time when it seems that nothing is going to turn out right and you want to give up. However, Musk companies seem optimistic even when they are in a difficult situation.

"Musk has long wanted the world to know that he's different from the run-of-the-mill entrepreneur in Silicon Valley" [14].

To want has the meaning "to have a desire or a wish for something/somebody" [13], i.e., desire, feeling that is inherent in every human being, is also part of the lexical-semantic field of SUCCESS. Moreover it is the proof of the fact that every person, if they wish, can succeed.

Conclusions. Thus, the analysis of the lexical-semantic field of SUCCESS concept which exists in the investigated novel around the personality of Elon Mask proved that the creation of the image of a successful person is achieved through the use of various lexical-semantic means, mainly words denoting action and status. This indicates that action is the most important factor in achieving success. Although internal and external qualities of a person, the attitude of society and the individual's attitude to his or her personality as well as the specificity of their activity field play an important role in succeeding.

Thus a successful personality is the one that: carries out effective professional activity (chairman, shareholder, investor); is marked by contradictory, heterogeneous internal characteristics (sheepish however confident; charming but too eager; genius while being insane); characterized by a balanced internal state (desire to achieve something) that turns into action (to try, to make, to tackle, to accomplish, to own, to stride, to built, to invest, to prove, to use); appearance shows success and confidence (broad-shouldered, sturdy, thick); treats himself or herself as a successful person, believes in own potential ("I am a billionaire") and it shows to the society that reciprocates and tends to have the same attitude ("He is a deity"); is the best in a certain field of activity (most famous and successful, better than most); makes good profits (one of the richest men in the world). Finally the main semantic groups of words denoting SUCCESS are: appearance, character qualities, work activity, attitude, psychological status, advantages over other people in one way or another and material wellbeing.

\section{References:}

1. Ангелова М. «Концепт» в современной лингвокультурологии. Актуальные проблемь английской лингвистики и лингводидактики. Сборник научных трудов. Вып. 3. Москва, 2004. С. 3-10.

2. Вежбицкая А. Понимание культур через посредство ключевых слов. Москва : Языки славянской культуры, 2001. 288 с.

3. Володина Н. Концепты, универсалии, стереотипы в сфере литературоведения : монография. Москва : Флинта ; Наука, 2010. 256 с.

4. Воркачев С. Куда ж нам плыть? Лингвокультурная концептология: современное состояние, проблемы, вектор развития. Язык, коммуникация и социальная среда. Вып. 8. Воронеж, 2010. С. 5-27.

5. Воркачев С. Лингвокультурология, языковая личность, концепт: становление антропоцентрической парадигмы в языкознании. Филологические науки, 2001. № 1. С. 18-22.

6. Загнітко А. Лінгвістика тексту: теорія і практикум. Донецьк : Юго-Восток, Лтд, 2007. 313 с.

7. Карасик В. Языковой круг: личность, концепты, дискурс. Волгоград : Перемена, 2002. 477 с.

8. Ключка Н. Лексико-семантичне поле як системно-структурне утворення. Наукові записки. Серія «Філологічна». 2012. Вип. 24. С. 129-131.

9. Колесов В. Концептология : учеб. пособ. Кемерово : КемГУ, 2012. Вып. 16. 248 с.

10. Кононенко В. Концепти українського дискурсу : монографія. Київ, Івано-Франківськ : Плай, 2004. 248 с

11. Приходько А. Концепти і концептосистеми в когнітивно-дискурсивній парадигмі лінгвістики. Запоріжжя : Прем’єр, 2008. 332 с.

12. Чернейко Л. Имя СУДЬБА как объект концептуального и ассоциативного анализа. Вестник Московского университета. Серия 15 «Филология». 1996. № 6. С. 20. 
13. Cambridge Dictionary. URL: https://dictionary.69.org (дата звернення 20.09.2019).

14. Vance E. Elon Musk: Tesla, SpaceX, and the Quest for a Fantastic Future. Virgin Books, 2015. 400 p.

Головня А. В. Текстове втілення концепту УСПІХ у романі Ешлі Венса «Ілон Маск. Tesla, SpaceX i шлях у фантастичне майбутнє»

Анотація. Стаття присвячена дослідженню текстового втілення концепту УСПІХ у романі Ешлі Венса «Ілон Маск. Tesla, SpaceX i шлях у фантастичне майбутнє». Концепт УСПІХ посідає особливе місце в англомовній картині світу. Наразі SUCCESS в ній має три групи значень: перше пов'язане з удачею, успішним результатом, друге - 3 добробутом, третє - 3 визнанням, яке може стосуватися як неживого об'єкта, так і людини, яка має успіх. Концепт УCПIX/SUCCESS пройшов безліч стадій культурно-історичної еволюції, оформившись у кінцевому результаті в сильну і функціональну національну ідею. Концепт УСПІХ у проаналізованому творі здебільшого стосується постаті Ілона Маска як успішної особистості; компаній, які створив Ілон Маск; інших особистостей і компаній, згаданих автором. Лексико-семантичне поле концепту УСПІХ, яке головним чином існує у творі довкола особистості Ілона Маска, активно вербалізується низкою лексико-семантичних засобів різних мовних рівнів. Семантичні особливості таких лексем поділяються на такі групи: назви людей за родом діяльності, за внутрішніми якостями, за характеристиками, які вказують на ставлення оточення й особистості до самої себе; назви, пов'язані 3 фізичними й психічними характеристиками та слова на позначення дії та стану. Аналіз лексико-семантичного поля концепту УСПІХ показав, що створення образу успішної людини досягається завдяки використанню різного роду лексико-семантичних засобів, серед яких, як було виявлено, переважають слова на позначення дії та стану. Це свідчить про те, що саме дія є важливим чинником на шляху до досягнення успіху, хоча, безперечно, внутрішні й зовнішні якості людини, ставлення соціуму й власне ставлення людини до своєї особистості, а також рід іiі занять відіграють важливу роль у процесі досягнення успіху.

Ключові слова: концепт, картина світу, УСПІХ, лексико-семантичне поле, вербалізація. 